Boston University School of Law Scholarly Commons at Boston University School of Law

Faculty Scholarship

$12-2015$

\title{
The Women of the Wall: A Metaphor for National and Religious Identity
}

Pnina Lahav

Boston University School of Law

Follow this and additional works at: https://scholarship.law.bu.edu/faculty_scholarship

Cart of the Comparative and Foreign Law Commons, Law and Gender Commons, and the Religion Law Commons

\section{Recommended Citation}

Pnina Lahav, The Women of the Wall: A Metaphor for National and Religious Identity, 30 Israel Studies Review 50 (2015).

Available at: https://scholarship.law.bu.edu/faculty_scholarship/201

This Article is brought to you for free and open access by Scholarly Commons at Boston University School of Law. It has been accepted for inclusion in Faculty Scholarship by an authorized administrator of Scholarly Commons at Boston University School of Law. For more information, please contact lawlessa@bu.edu. 


\title{
BU School of Law
}

\section{THE WOMEN OF THE WALL A METAPHOR FOR NATIONAL AND RELIGIOUS IDENTITY}

\author{
Boston University School of Law \\ Public Law \& Legal Theory Paper No. 16-05 \\ Israel Studies Review, Volume 30, Issue 2, Winter 2015: 50-70 \\ January 20, 2016 \\ Pnina Lahav \\ Boston University School of Law
}

This paper can be downloaded without charge at:

http://www.bu.edu/law/faculty-scholarship/working-paper-series/ 


\title{
The Women of the Wall
}

\section{- A Metaphor for National and Religious Identity}

\author{
Pnina Lahav
}

\begin{abstract}
The Women of the Wall wish to participate in communal prayer in the women's section of the Western Wall in Jerusalem. Their practice is to pray as a group, wrap themselves in a tallit, and read from the Torah scroll. They represent Jewish pluralism in that their group includes Orthodox, Conservative, Reform and secular women. They represent openness to change in that they base their claims on Halakhic interpretation, thereby embracing the capacity of Jewish law to evolve. This article reviews the resistance of the religious and political establishment in Israel to their claim and their struggle, unsuccessful so far, to get recognition.
\end{abstract}

KEYWORDS: feminism, freedom of worship, High Court of Justice, Jerusalem, law and religion, religious pluralism, "women of the wall"

The "Women of the Wall" (hereafter WoW) and their struggle for space at the Western Wall in Jerusalem offer a metaphor for Israel's evolving national identity as well as for pluralism in Judaism and in progressive society. This article elaborates on the substance of this metaphor.

WoW is a group of women, Israeli as well as citizens of the Jewish Diaspora (American, Canadian, Australian, French, Brazilian, and more) who wish to hold communal prayers in the women's section of the holiest of Jewish sites, the Western Wall in Jerusalem. Because some of them are Orthodox, the group adheres to the Orthodox custom of gender-based segregation during prayer. Members of the group wrap themselves in a tallit, read from the Torah, and sing in keeping with the traditional service.

WoW's claim that women's communal prayer is not prohibited by Halakhah is no longer novel. Many rabbis have validated this claim and the 
practice of women's prayer groups has been accepted in many Orthodox synagogues around the world. But in Jerusalem, where ultra-Orthodox rabbis are in charge of the Wall, this practice is considered heresy.

The struggle of WoW has triggered litigation, deliberations by commissions, parliamentary debates and legislative bills, cabinet crises, and arrests of women as they pray. More recently, various Jewish religious movements in the United States have come to be actively involved in the struggle. Also, a solution has been offered that involves exiling the WoW from the women's section into an adjacent space, known as the Robinson Arch. Whether this solution will indeed materialize and how it will affect WoW remains to be seen.

Why do the Orthodox in Jerusalem consider WoW's practice heresy? Traditional Jewish service requires a minyan, a group of ten individuals. Traditionally and historically only men served in a minyan (Shochetman 2010: 291). Some Jerusalem rabbis accept that Halakhah does not ban the inclusion of women, but they profess loyalty to custom, which expects only men to be included. Therefore, they argue, women may pray silently as individuals but not as a group.

WoW is a metaphor because it stands for a concept of Jewishness that fits well with Zionist ideals, the democratic component of the State of Israel, and a forward-looking and inclusive Judaism. WoW also stands for the Jewish pluralism practiced by the majority of Jews around the world. Furthermore, WoW stands for the morality of the rule of law — both secular and religiousa notion of law that is based on human dignity and a profound sense that change in the law is imperative as life moves on and culture evolves.

The wave of gender-based segregation so evident in Israel today, of which the segregation in buses is only one example, should be understood and explained through the lens of WoW. The backlash against tolerance, pluralism, and gender equality begins with WoW's demand for recognition. It is therefore particularly important to understand their story.

\section{WoW: A Collective Biography}

In 1988 an international conference dedicated to women's issues was held in Jerusalem (Lahav 2013b; Chesler and Haut 2003). The conference attracted women from many corners of the Jewish world. Rivka Haut, an Orthodox woman from New York, had an idea: the participants should borrow a Torah scroll from one of Jerusalem's progressive synagogues and make a pilgrimage to the Western Wall to conduct a communal prayer service. Throughout the 1980s in New York, she had actively spread the idea of the legitimacy and desirability of women's prayer groups (Grossman 
2014). But in 1988 her project was still novel, seemingly attractive to few and startling to many.

The space of the Wall, the most sacred place in Judaism, is presently operated as a traditional Orthodox synagogue. In keeping with tradition, the plaza adjoining the Wall is divided into a large section for men, and a rather narrow section for women, separated by a fence. When Haut's group began their communal service, the worshippers present at the site were at first flabbergasted. What they witnessed was so alien to their worldview that they could barely believe their eyes. But soon enough they concluded that they were witnessing the essence of heresy. Perceiving themselves as 'guardians of the faith', they took the law into their own hands, determined to nip the practice in the bud. There and then WoW was born.

The participants at the 1988 conference came mostly from abroad, primarily from the United States. Not all of them were religious, and their religiosity itself was diverse. They reflected the pluralistic and tolerant nature of American Jewry. Some were Modern Orthodox, some Conservative, Reform, even secular. However, they were united by the commitment to gender equality. As Americans, the members of the original group had already been sensitized to feminism, to the struggle by women to partake in all spheres of life, including religious life, and to the activism that life in civic society entails (which is why they came to Jerusalem).

As Americans, too, they were accustomed to a constitutional order. The ethos of American constitutionalism is that the constitution enshrines certain universal principles that cannot be violated. Among them is the free exercise of religion (the First Amendment) and the equal protection of the law (the Fourteenth Amendment). The American ethos also holds that in case of violation one may petition the court and, if the petition is upheld, the practice will be declared unconstitutional. Americans also expect the executive branch to implement the court's decree.

But that would be true in the United States. Was Israeli fundamental law violated as well, and would an Israeli court declare the practice invalid? The American members had some reason to believe that this was so.

Israel is one of the few democracies that does not have a formal constitution, but both the principles of free exercise of religion and of equality have been recognized as being part of the Israeli constitutional system. ${ }^{1}$ Furthermore, just as WoW was beginning to articulate its cause, Israel's High Court of Justice was gaining a reputation for actively defending political and civil liberties. ${ }^{2}$ I shall not elaborate on this development, but only note in passing that it was a part of a larger transformation of Israeli society into a more civic and rights-oriented polity. Two examples are directly relevant. In 1987, a Modern Orthodox woman, Leah Shakdiel, challenged the refusal of the Minister of the Interior to consider her 
application to serve on a religious council. ${ }^{3}$ Never before had a woman been included in such a body. The Court ordered the Minister to consider Shakdiel's application on its merits (Woods 2008: 160-163).

That same year, the city of Tel Aviv was preparing to elect its chief rabbi. The Orthodox refused to let women council members vote in the election of a rabbi. The women petitioned the Court and won: a rabbi, who was a government employee, was subject to the laws of the state (Halperin-Kaddari 2004). ${ }^{4}$ These recent (1988) gains in gender equality could persuade the skeptics that the ground was ripe to vindicate WoW's right to pray at the Wall. ${ }^{5}$ After all, what did they want? Merely to pray in accordance with Orthodox principles, confined to the women's section, and behind the mehitza.

In the United States, the American group formed the ICWoW (hereafter International Committee for the Women of the Wall). In this group were experienced veterans of the civil rights and feminist movements, who knew well how to organize a social movement. Prominent in the group was Phyllis Chesler, a well-known author, psychologist, feminist, activist, and theoretician of women's issues. Chesler was a formidable force in establishing and nurturing the ICWoW. But the nascent social movement confronted the constraints of being not only women and Jewish, but members of the larger community of American Jews. The loaded question of the relationship between the Diaspora and Israel was thus placed on the table.

The ICWoW looked upon Israel as a progressive polity that shared American values and sensibilities. ${ }^{6}$ They were not sufficiently aware of Israel's complex reality, where constitutionalism was only beginning to assert itself and where Orthodoxy was reified, fundamentalist, patriarchal, and in possession of increasing political power. Their challenge brought them into conflict not only with the Orthodox, who expected women to be deferential in matters of religious rites, but also with Israel's foreign affairs reality.

As soon as the ICWoW embarked on their campaign, a potential conflict with the leadership of the Jewish community emerged. This leadership was largely devoted to defending the State of Israel in the context of the Arab-Israeli conflict. It therefore was quite sensitive to any issue that might cast a negative light on it, and thus influence American public opinion against it. Furthermore, when defending Israeli interests, the US Jewish community was always striving to present a united front, but the issue of WoW was divisive. The ICWoW was urged to display awareness of this sensitivity. A vocal movement, calling attention to the fact that in Jerusalem Jewish women were denied freedom of religious worship flew in the face of the claim that Israel alone could be trusted with maintaining equal access to the holy sites. It is quite likely that the ICWoW was urged to "be discreet" and shun the general media in order to avoid giving ammunition to critics of Israel (Aronoff 2003). ${ }^{7}$ 
Thus, the ICWoW found itself at a disadvantage. It did not, perhaps could not, use the tools and skills that its leaders possessed to alert American and world public opinion to this strange phenomenon, that freedom of Jewish worship, the freedom of women to pray in accordance with their legitimate (if controversial) beliefs, is denied by the State of Israel. In the process of subordinating their rights to what they perceived to be the "Jewish interest", the ICWoW tragically walked in the footsteps of their mothers and grandmothers: women's rights were again sacrificed on the altar of a perceived greater good, defined largely by men. ${ }^{8}$

The Israeli women who were among the original group had much in common with their international sisters, but they were also markedly different. Their concern was for their civil rights in their own country of residence. The Israelis felt about communal prayer at the Wall exactly the same way Chesler and her sisters felt about any issue of gender equality in the United States. For them, the politics of the American-Jewish community and its worries about American public opinion in matters of foreign affairs were less relevant. ${ }^{9}$ And there were more differences between the two groups.

First, religious pluralism, while taken for granted in the United States, had been (and to a large degree still is) a marginal phenomenon in Israel. Israeli 'Jewish identity' and American 'Jewish identity' are not the same. Most of the founders of Zionist ideology viewed religion as a relic of the past. The emerging Israeli society was encouraged to embrace a secular lifestyle and distance itself from 'the dark clerical past' of rabbinic rule. A small space was carved out for the Orthodox minority, and a metaphorical wall separated the two communities. Conservative and Reform lifestyles were practiced in tiny local communities, mostly by immigrants from English-speaking countries, and were not supported by the state apparatus. The religious part of the Israeli public, including those who call themselves 'traditional' (masorti-selectively observing the principal tenets of the religious way of life), has been predominantly Orthodox, especially when it comes to the status of women.

Second, and no less important, theories of feminism and gender equality have been slow to penetrate Israeli consciousness. In 1988, the Israeli public was largely indifferent to feminism and most accomplished women kept their distance from it. Thus, most of the Israeli activists who attended the 1988 conference were more interested in the agenda of promoting gender equality in the secular Israeli world, and less aware of, or concerned with, the significance of women's communal prayer. To make a commitment to the cause of WoW, Israeli feminists had to embrace the concept of religious pluralism. The agenda of feminist reform was ferociously crowded and its priority list long. The issue of WoW was quite low on the Israeli agenda. 
The reluctance of the Israeli feminist camp to rally around WoW has deeper causes as well. Israeli feminists have resented rabbinical control in matters of marriage and divorce. The discriminatory practice of communal prayer was dwarfed by the suffering of Israeli women seeking divorce or support in other family matters. WoW was both a reminder of their own helplessness in fighting the rabbinical establishment and a dangerous return to religious practice (prayer), when the goal should be to break religion's hold on a woman's freedom and dignity (such as getting a divorce or an adequate financial settlement upon divorce). However, those Israelis who were members of WoW did not see it this way. They sought both Halakhic change and reform across the board, and believed that just as they could show that communal prayer was permissible, so they could show the potential of Halakhic reform to make divorce more compatible with women's dignity and rights. Thus, the Israeli feminist agenda was itself a major problem for WoW as they sought support for their cause.

It is important to re-emphasize that WoW itself is diverse and complex. At a minimum, it is divided into two groups; the Israeli chapter and the international chapter. The fence separating them is low and somewhat invisible. Members move from one group to the other as they change their place of residence or their interpretation of current or past events. But the milieu within which they operate (Israel for WoW, the United States or Canada for ICWoW) affects them in different ways. As will be discussed, the opposition among WoW to the 'egalitarian plaza', a solution proposed in 2013, is led mostly by ICWoW. These constraints add to the woes of WoW.

The woman endowed with natural leadership gifts who eventually became the Israeli leader of WoW, Anat Hoffman, came to embody its agenda (Berman 2013). A member of Ratz (the Civil Rights Party, advocating a rigorous separation of church and state similar to the American model) and later of Meretz, a larger left-wing party with a similar agenda, she gradually became part of the Movement for Progressive Judaism (Israeli Reform Judaism) and developed a passion for restoring a place for non-Orthodox Jewish religious life in Israeli identity. With the help of the US Reform Movement, she established the Israeli Religious Action Center (IRAC) and developed a plan to transform the Israeli cultural landscape into one accepting of religious practices that are inclusive and progressive. In doing so, she has been fighting an uphill battle with the hostile Orthodox camp, the indifferent secular public, and the state, which eventually came to side with the Orthodox. At the same time she had to negotiate with her partners in the United States (the ICWoW).

All of the above illustrate the woes of WoW. The maze that they have been forced to navigate is formidable indeed. WoW was forced simultaneously to confront two legal systems, each with its own dynamics and 
limitations: the Israeli legal system and Halakhah as understood by the Orthodox camp. The woes of WoW have not only been sociological and geographical. They were also distinctly legal.

\section{The Road to Litigation}

Situated within a Western-style democratic state, Israeli constitutional law attempts to uphold the principles of the separation of church and state and of the free exercise of religious worship. Haut's concept of women's prayer groups has never been prohibited in Israel. Women could always congregate in a private space of their choice, or indeed establish their own synagogue and fulfill their yearning for the experience of communal prayer. ${ }^{10}$ The controversy erupted because WoW has been insisting on holding their communal prayers at the site of the Wall-the most public religious space in the Jewish world. WoW wanted to make the point that their 'place' was not only at home but in the public realm as well.

For centuries, Jews were discouraged from coming to the Wall for prayer. Pre-state photographs reveal that men and women mixed at the site of the Wall. The separation of men and women was not a part of the custom at the Wall. In 1948, Jordan occupied the Old City of Jerusalem, including the Wall, and prohibited any Jewish presence there. The 1967 War united the city and brought the Wall under Israeli control. Within days, a vast plaza was created and the Wall came under the jurisdiction of the Ministry of Religions. The Ministry promptly established a mehitza (fence) to separate men from women, in keeping with Orthodox practice. The men's section was well supplied with Torah scrolls and folding tables appropriate for conducting religious rituals. Women were allocated a small space stocked only with regular prayer books (siddurim). This was what Haut's group encountered when it first arrived at the Wall to conduct a communal prayer (Triger 2013).

Since 1967, Israel's government has emphasized the significance of the Wall in Jewish heritage. It is small wonder that Haut felt the Wall would be the most appropriate place to hold the group prayer. Even the government would agree that an ordinary synagogue would not open the wells of yearning and inclusion that the Wall could. Nor could an ordinary synagogue send the message that women have arrived as equal citizens. The connection between Israel, women's rights, and Judaism could best be communicated through communal prayer at the Wall.

At this juncture it is important to consider the concept of 'Orthodoxy'. Jewish Orthodoxy is a continuum. At one extreme are Haredim, some of whom deny the legitimacy of the State of Israel. The continuum contains 
diverse elements of Modern Orthodoxy attempting to reconcile the Jewish lifestyle and modern society (Barzilai 2003: 209). Haut was a radical within the Modern Orthodox camp and a pioneer of women's prayer groups, a concept that in the 1980s was resisted by the Orthodox world. The Wall synagogue was administered by Haredi men who could not empathize with Haut's demands (Shakdiel 2002: 126).

A large measure of naïvete lay at the core of Haut's high expectations. Haut's group underestimated the fierce opposition the Haredim hold against anything untraditional. Nor did WoW understand the political dynamics of the relations between religion and state in Israel, or its impact on Israeli law.

When the worshippers at the Wall unleashed their rage at Haut's group, the participants expected police protection, not to mention sympathy. After all, they were modernizing Jewish religion and bringing it in tune with its glorious heritage of equality and justice. At the scene of the Wall, vehement verbal abuse and invective soon culminated in physical assault. Haredi men hurled metal chairs at the members of WoW, threw them to the ground in anger, and even discharged tear gas grenades (on hand to disperse Palestinian demonstrations) (Haberman 2003: 18). The police chose the role of passive observers. They allowed the rage to sizzle for a while and finally moved to arrest a few of the women participants, claiming that it was they who had broken the law (breach of the peace) by offending the feelings of the worshippers (Chesler and Haut 2003: 4-6). Shortly afterwards, the Rabbi of the Wall, using his statutory authority, issued a regulation prohibiting any prayer on the premises of the Wall that contravened 'the custom of the place' (minhag hamakom). ${ }^{11}$

For American women, heirs of the civil rights movement and accustomed to judicial protection of First Amendment rights under the US Constitution, these events were quite upsetting. The state's complicity, putting secular law at the service of the Orthodox establishment, opened their eyes to their being 'others', and ignited a determination to fight one more vestige of sex discrimination.

Back in the United States, ICWoW made plans to sue, and it persuaded its Israeli sisters to join in (Benson 2003: 136). Thus far they had been dealing with the executive branch of the government. Now they came to court. The international flavor of WoW again became apparent. Much of the financing of this protracted litigation was supplied by sources outside of Israel. ICWoW intimately identified with the struggle, which concerned their identity as Jewish women. Furthermore, support for WoW added to the general American effort to cultivate a civic society in Israel, thereby deepening Israel's democratic culture and perhaps making it more similar to the United States. Thus began a process of protracted litigation before Israel's High Court of Justice. 


\section{The Legal Battle}

What was the legal framework of the controversy? The Rabbi of the Wall was serving two masters. On the one hand, he was an employee of the Ministry of Religious Affairs and bound by secular Israeli law. On the other hand, he was a distinguished rabbi, committed to life within the four corners of Halakhah, and very much a part of the Orthodox religious establishment.

The Rabbi's refusal to allow WoW freedom of religious worship at the women's section placed Halakhah in direct conflict with Israel's secular law. WoW and ICWoW petitioned Israel's High Court of Justice to enforce well-accepted principles of Israeli law: all government employees must abide by state law; state law includes the principles of separation of church and state, free exercise of religion, and gender equality (HalperinKaddari 2004: 170; Raday 2003: 115). Therefore, the Rabbi of the Wall must accept the presence of WoW in the women's section.

However, these principles, so easily comprehended by the modern citizen of a secular state, at least on the abstract level, are not as accessible to adherents of a religious worldview. Israeli Orthodoxy tolerates a duality of legal systems only if its leaders do not perceive conflicts between the two.

The government at the time was led by Prime Minister Yitzhak Shamir, a fervently secular man whose coalition included several religious parties. It faced a hard choice: uphold the well-articulated principles of the rule of law and respect WoW's rights and face a possible coalition crisis, or side with the Orthodox and reject WoW's petition. Shamir himself had no interest in the issue. Of course, representatives of the secular government of Israel would not go so far as to state that they were willing to violate cherished constitutional principles. However, they could and did resort to the justification that the WoW practice offended the feelings of the worshippers at the Wall and should be prohibited on that ground. This argument has continued to be voiced by the opponents of WoW throughout the protracted confrontations.

Many of the cabinet ministers at the time, like Shamir, were personally agnostic about the issue of women prayer groups; still, they sided with the Orthodox camp. Need for the political support of the Orthodox combined with failure to understand notions of gender equality and puzzlement at WoW's request tilted the balance against WoW. It was easy to ignore the feelings of the women while empathizing with patriarchal traditions. If a secular male politician does not value his own right to pray, why should he value the right of a woman to do so?

But things became ever more complicated. The conflict opened a controversy between rabbis and scholars of Halakhah. Some held that Halakhah 
categorically limited communal prayer to men, whereas others, equally learned, argued that Halakhah is either supportive of women's communal prayers or at least is ambiguous about it (Sperber et al. 2010). ${ }^{12}$

Between these interpretations of Halakhah, should the secular High Court take a stand? The conflict furthermore triggered disagreement about secular Israeli law. Should the Court view this issue as a case of first impression and analyze it with analytical tools from feminist legal theory and civil rights theory? Or should the Court defer to the 'status quo', whereby the Orthodox are the guardians of the religious lifestyle (Rubinstein and Medina 2005: 378)?

Moreover, the hard question of territorial identity was raising a different issue. If Israel was the homeland of all Jews, then certainly members of ICWoW had a right to petition the Court for redress of grievances. But if Israel was a state 'like all states', with a distinct Israeli culture and citizenry, then members of ICWoW were foreigners trying to intervene in domestic affairs (Sered 1997: 138). Their Israeli sisters were likewise 'otherized'. Many of them had ties to the United States and were accused of adopting an 'American practice'. The rumor spread that WoW were American women seeking to bring their Reform customs (anathema to the Orthodox) to the Wall. The fight thus was identified as a part of the historic struggle between orthodoxy and reform in Judaism, ignoring the insistence of WoW that they were praying in accordance with Orthodox principles.

Particularly at the sacred space of the Wall, the Jewish pluralism from which WoW sprang appeared as a radical departure from the natural order of things. ${ }^{13}$ Well aware of the enormous resistance, WoW asked for permission to pray only once a month, on Rosh Hodesh, at 7:30 in the morning. Rosh Hodesh, the beginning of the lunar month, is halakhically designated as a day dedicated to the welfare of women; hence the expectation that communal prayer on that day would receive special leniency, even in Orthodox circles. WoW also imagined that this extremely modest request would make it easy for the Court to accept their petition. However, several, not merely two, worlds collided and challenged the Court in acute ways.

The first three rounds of the legal battle lasted from 1989 to 2003 and ended in an enforced compromise. WoW was asked to leave the women's section and move to an adjacent space. After protracted controversy and endless negotiations, the government agreed to prepare an alternative site at a nearby archeological garden known as the Robinson Arch. However, the Arch, formally a part of the ancient wall of the Second Temple, has never been perceived to be as sacred as the Wall area, and it is located several hundred meters from the Wall itself. It is also difficult to renovate, because it contains important archeological artifacts and is subject to the laws governing archeological sites. Nevertheless, the Robinson Arch area 
was somewhat renovated to allow the women access (including the handicapped). Members of the Reform and Conservative denominations, where mixed-gender prayers are the norm, were invited to pray there. At present the site looks like a makeshift location, lacking the dignity of a place of worship or the deep spiritual feelings associated with the Wall.

Returning to the trajectory of the legal battle: there is no doubt that the government agonized about the matter. Two factors must have weighed heavily in favor of the status quo and against WoW. The Israeli Orthodox are a fairly sizable group, and the religious parties hold significant leverage in the Knesset and often in the cabinet. For example, it is doubtful that a peace process involving the end of the Occupation can take place without the support of at least some of these parties. The second factor is Israeli secular consciousness. Until very recently, Israelis felt comfortable with the grand compromise of Zionism: religious practice would be monopolized by the Orthodox, while the majority of Israelis would remain secular. This majority, feeling itself removed from religious matters, could not appreciate WoW's significance for Israeli and Jewish life. These factors fed the government's decision to lean against WoW.

ICWoW took the lead. They hired a prominent male attorney and planned to petition the High Court of Justice for an injunction. The Israeli WoW preferred a female attorney to represent them. Again, this episode, which deserves further documentation, illustrates the internal woes of WoW. Ultimately, a prominent woman attorney, Hebrew University Law Professor Frances Raday, agreed to represent WoW. ${ }^{14}$

As Raday was fighting on behalf of WoW, she was also conducting an array of other legal battles before the Court. WoW's battle must be understood in the context of the larger struggle of Israeli women for equality. In the late 1980s and early 1990s, gender-based discrimination was rampant. Women's income was significantly lower than men's; age discrimination in the workplace compelled women to retire before men; leadership positions in the military, the apple of Israel's eye, were closed to women; and sexual harassment was perceived as a natural male entitlement. It could be expected that WoW's struggle would land low on the priority list. ${ }^{15}$ Unsurprisingly, the High Court displayed little enthusiasm to spend its political capital, already low among Orthodox Israelis, on supporting WoW's petition. The litigation yielded three rounds of opinions by the High Court of Justice, in 1994, 2000, and 2003.

\section{The First Round}

Israel's High Court of Justice, composed of the fifteen Supreme Court justices, is charged with enforcing the law against government officials, 
and typically sits in a panel of three justices. Three male justices were appointed (at that time two women justices were serving on the Court) to review the petition: Chief Justice Meir Shamgar and Justice Shlomo Levin, both secular men, and Deputy Chief Justice Menachem Elon, a Modern Orthodox Jew and international authority on Halakhah.

The petition was submitted in 1989, and the decision was delivered in 1994. After five years, the Court, as was increasingly its policy in political controversies, $d^{\circ}$ ecided to postpone the legal resolution of the case. ${ }^{16}$ Chief Justice Shamgar held that WoW's claim indeed had merit but, because of the sensitivity of the issue, he recommended that the government establish a commission to develop an appropriate solution. Justice Levin concurred, but his rhetoric displayed a more resolute commitment to the free exercise of religion. WoW, he insisted, had a right to pray at the Wall. Justice Elon delivered an encyclopedic opinion, concluding that indeed Halakhah permitted women to pray communally. But then Justice Elon made a surprising U-turn. Custom, he opined, reserved the right to men. Unity of worship at the Wall required that WoW sacrifice its right to pray. The High Court sent the ball back to the government, which was told to find a solution to WoW's petition.

More time passed. Prime Minister Yitzhak Rabin was assassinated in November 1995 (by a young religious man determined to derail the peace process, which he thought violated Halakhah), and in the 1996 elections the Orthodox gained more power. Commissions (composed exclusively of men) were appointed, dragged their feet, and failed to reach conclusions. In 1999, almost ten years after the initial events, the Court agreed to rehear WoW's case.

\section{The Second Round}

As the twenty-first century dawned, the Court issued a unanimous opinion in favor of WoW. Three justices-one man, Justice Eliyahu Matza, who wrote the opinion for the Court, and two women, Justice Tova Strassberg Cohen and Justice Dorit Beinish (later appointed Chief Justice, now retired)—authored a well-reasoned and superbly crafted opinion. The opinion made clear that it was the duty of the government to protect the women as they exercised their right to freedom of worship. Nevertheless, the Court did not order the government to let the WoW pray. It gave the government six months to make appropriate arrangements. ${ }^{17}$

In June 2000, the attorney general requested the Court to grant the state a further hearing and reconsider that opinion. The Court acquiesced. The attorney general's request could only be explained in the context of the political volatility of the conflict and its high profile. 
By the year 2000, the High Court no longer enjoyed the status of an invincible, revered institution. A backlash was taking place, targeting, among other things, the Court's liberal position in matters of separation of church and state (Mautner 2010). One may imagine (although this author has no proof) that then Attorney General Elyakim Rubinstein, who is Orthodox, must have experienced external as well as internal pressure to derail the Court's opinion. The Court itself must have understood the volatility of the situation when it granted the attorney general's request for a further hearing. Rubinstein has since been promoted to the Supreme Court and is now a senior justice.

\section{The Third Round}

Nine justices sat on the panel that reviewed the unanimous opinion delivered in the second round. Among them were Chief Justice Aharon Barak and Justice Mishael Cheshin, both secular, known for their brilliant legal skills as well as their commitment to the separation of religion and state. Again, the Court took its time, and rumors were that intense behind-thescenes negotiations were taking place to find a compromise. In 2003, a sharply divided Court recognized WoW's right, but sided with the government's argument that the Wall should be kept under the patriarchal umbrella. The majority recognized WoW's right to hold group prayer at the women's section of the Wall, but opined that, under the circumstances, they should go someplace else. The Court did, however, warn the government that if it failed to provide an adequate alternative, the Court might issue an injunction on behalf of the women. ${ }^{18}$

\section{WoW and the Concept of the Rule of Law}

The case of WoW deserves at least a dissertation (not offered here) focusing on the trials and tribulations of the rule of law. In every stage of the struggle, the principles at issue (equality, freedom of worship), well-entrenched in Israel's legal system, were compromised because of fierce pressure by Orthodox circles prevailing upon the Israeli government to take their side. Even the High Court of Justice fell into the practice of ignoring straightforward principles as well as its own well-reasoned unanimous opinion (second round), to avoid the gathering storm.

When the Orthodox first heard of WoW's claim, they insisted that Halakhah prohibits it. When an authority such as Justice Elon concluded that, in fact, Halakhah does not forbid it, they elevated custom into an entrenched principle that could not be compromised. 
After the Court gave its blessing to the Robinson Arch as an alternative venue, the Orthodox adopted another argument. If until then they had argued that Halakhah or custom trump Israeli civil rights law, they now piously wrapped themselves in the tallit of secular law. The Court, they now insisted, had sent the women to Robinson's Arch, and that verdict (law) must be obeyed.

A fourth round, resulting in an opinion by District Court Judge Moshe Sobel (below), holding that WoW does have a right to pray at the women's section of the Wall, upset the cozy relationship between secular and religious law. Now the Orthodox were back to square one, facing a secular judicial opinion that negated their claim to a monopoly at the Wall. They therefore abandoned their argument that the secular law must be followed, and again insisted that rabbinical law and custom was the supreme law of the land.

One wonders if we now face another metaphor for the legal confusion affecting the State of Israel. From the beginning of the controversy, WoW had offered a version of Halakhah that was in harmony with the secular law. This version recognized women's equality and dignity, i.e., that women, too, were created in the image of God. If adopted by the Rabbis, the entire conflict could have been avoided. But the Rabbis placed custom on par with Halakhah and thus tilted the balance against equality and in favor of patriarchal values. Their actions with regard to WoW are emblematic of the campaign presently raging in Israel to exclude women from the public sphere: in buses, in military service, and elsewhere.

\section{3: Escalation, a Tentative Judicial Victory, the Search for Compromise- An Unending Saga}

By 2004, WoW seemed to be losing both in court and in the legislative arena. Nevertheless, this group of determined women proved to be remarkably resilient. An argument had been raging in legal academic circles as to whether progress is better achieved through victories in court or through social mobilization. In this case, once WoW understood the limits of law, it turned to social action.

They have succeeded in harnessing technology to their cause. WoW has a website and an electronic newsletter, they are on Facebook, and they tweet. They try to mobilize support for their cause through various projects, such as selling hand-made tallitot with the names of the four Jewish matriarchs embroidered on the four corners, and they encourage tourists to hold bat mitzvah and other celebrations with them. They spread the message of sisterhood and gender equality and rally support against segregation. Two film documentaries track their struggle (Katzir 2009; Lederman 2000). 
For a while, WoW attempted to hold their rituals discreetly at the site of the Wall. For a while, the police turned a blind eye, and on occasion even quieted zealous male worshippers (perhaps another indication of the ambivalence of the executive branch). WoW pointed out that the government was dilatory in its renovation of the Robinson Arch and that it was therefore not a viable alternative to the Wall. They kept invoking the image of Rosa Parks, who refused to bow to racial segregation in the American South. Also, they benefitted from the work of numerous rabbinical scholars, men and women, who offered more learned justifications to support their claim. This scholarship strengthened WoW's argument that they were within the four corners of the law, both Jewish and secular, and that they were the victims of grave injustice (Sperber et al. 2010: 27).

The more WoW was rebuffed, the more it became the harbinger of the general theme of gender equality in Jewish religious life in general, and in Israel in particular. For its part, the opposition also rallied its troops and its influence. I shall address the opposition first, and then discuss two important events occurring in 2013.

At first, the opposition to WoW was made up of men only. Women were confined to the role of 'informers', alerting the men from behind the mehitza that the WoW had arrived. But even though the opposition is wedded to ancient patriarchal custom, they do not lack modern sophistication and probably enjoy the help of savvy PR professionals. Orthodox women were soon recruited to voice vocal, reasoned disapproval of WoW. Already during the litigation before the High Court, Orthodox women had filed a brief to challenge WoW. An organization called Women for the Wall (as distinct from Women of the Wall) waxed eloquent about the need for unity and deference to rabbinic authority (Aharoni 2013: 5). ${ }^{19}$ Reminiscent of the suffragists' struggle at the end of the nineteenth century and the beginning of the twentieth, groups of women were pitted against each other: one carrying the torch of inclusion, progress, and change; the other insisting on the supreme value of tradition and the status quo.

At some point in the second decade of the twenty-first century, the police resumed enforcing the ban of women's prayer groups. Members of WoW who came to pray at the women's section were arrested and jailed. ${ }^{20}$ They were forced to spend a night in incarceration, along with other criminal suspects (such as prostitutes), presumably in the hope that the experience and the humiliation would chill further activity. The women were then brought before a judge on charges of breach of the peace and a restraining order issued, preventing them from praying at the Wall for a period of time. WoW widely disseminated pictures of their members being dragged away by the police, wrapped in a tallit and holding a Torah scroll. These were not pretty pictures and they alarmed progressives in Israel and elsewhere. 
More visitors started attending the Rosh Hodesh events to support WoW. In the course of these developments, at least some secular Israeli women were transformed as well, spiritually discovering the beauty and meaning of Jewish services and the power of praying together. ${ }^{21}$

In April, 2013, five women were detained by the police and brought before Judge Sharon Larry-Bavli. She reviewed the (video) evidence presented by the police and determined that none of the detainees had engaged in violence or were in breach of the peace. The government's request for a restraining order was dismissed. The claim that the mere appearance of WoW at the women's section, without more, constitutes a legal provocation to violence that was rejected. The Government appealed the verdict in the case known as State of Israel v. Rus. ${ }^{22}$

The appeal came before District Court Judge Moshe Sobel. On 24 April 2013, he sent a lightning bolt across the Jewish sky, shaking and reordering the previous balance of power. His ruling held that Israeli law requires proof of actual provocation before the offense of breach of the peace may be applied. In this case, no such evidence existed. This holding strengthened the findings made by the lower court. Furthermore, he held that the High Court opinions in the matter of the Women of the Wall did not explicitly prohibit women's prayer groups at the Wall. He pointed out that a majority of justices did recognize WoW's right to worship at the Wall. The fact that they also urged all parties to opt for an alternative did not cast any doubt on that legal right. Therefore WoW was not violating any law when they organized group prayer at the Wall. It was a formidable opinion, superbly crafted, and well written. In my view, the fact that it was highly legalistic and devoid of rhetoric augmented its power in the current climate (Lahav 2013a). ${ }^{23}$

Israel is a country generally respectful of the rule of law, and once Judge Sobel's opinion was announced, the government ordered the police to refrain from arresting the women. Also, Israel's Attorney General, Yehuda Weinstein, issued a set of recommendations to combat gender segregation in the public sphere, including a recommendation to criminalize such segregation. ${ }^{24}$

The Orthodox launched an unprecedented counteroffensive against WoW. Rabbis summoned young seminary girls to take a day off school and fill the women's section of the Wall, thereby leaving no room for WoW's members to pray. They did not hide their determination to derail WoW by all available means. It is too early to tell whether this move will be successful or whether it might backfire.

It appears that the government did understand that public outrage, especially outside of Israel, hurts Israel's reputation as a democracy as well as a Jewish state, committed to all Jews, men as well as women. If until the events of 2013 the cabinet was in no hurry to find a solution, it now felt the 
heat. Together with Natan Sharansky, head of the Jewish Agency, the Robinson Arch option was again placed on the table.

At the same time, a plan was submitted to the Prime Minister to expand the Wall Plaza. The Wall itself would remain in Orthodox hands, but an equally large plaza will be constructed, called 'Ezrat Yisrael', where members of WoW and the Reform and Conservative movements could hold prayers in accordance with their own customs.

WoW was not happy about this solution because it required their consent to discontinue worship at the women's section at the Wall. In particular, WoW's Orthodox members objected that the new plaza will have no mehitza or women's section, a situation unacceptable to them from their Modern Orthodox Halakhic perspective. Behind the scenes, it appears that pressure was put on leaders of the Reform and Conservative movements in the United States to prevail upon WoW to accept a compromise and move to the Robinson Arch under the new plan. ${ }^{25}$

WoW did not have enough time to relish the victory of Judge Sobel's opinion or the increasing support it was receiving from both the domestic and international public. In deliberating the offer to move to a renovated Robinson Arch (or an "Ezrat Yisrael" if it ever materializes), a rift became visible within WoW's membership. The Orthodox members of WoW interpreted the decision to cooperate with the new plan as betrayal. They insist on their right to pray in the women's section of the Wall (Chesler 2013). ${ }^{26}$ Here is another woe of WoW. They were banned from the Wall under the pretext of unity, but in accepting a compromise they must sacrifice their own internal unity.

As this article is published, WoW's leader, Anat Hoffman, has announced that while accepting the new plan, the members insist on their right to pray at the women's section until the plan materializes. No one knows if it will. It is clear that WoW's road has been thorny, a neverending chain of woes. The group is a splendid metaphor for the status of women in Jewish culture, particularly in Israel. It courageously fights for the right to be equal under the law, Halakhic and secular, and it is rebuffed by followers of ancient patriarchal principles and by cynical politicians who look at their struggle as a mere nuisance.

The 2015 elections and the new Netanyahu government presently in office do not bode well for WoW. The Orthodox camp is stronger than ever and may insist on prevailing at the Wall. This stand may well pit progressive American Jewry, Conservative and Reform, but also Modern Orthodox, against official Israeli policies. The end of this controversy, unfortunately, is not in sight. 


\section{ACKNOWLEDGMENTS}

Previous drafts of this paper were written in the context of a year-long religion-fellows seminar at the Boston University School of Theology, 20102011. I thank members of the seminar for their insightful comments and suggestions. A part of this paper was presented at the University of Chicago Law School's conference, "What Pertains to a Man?" I am grateful to Mary Anne Case for inviting me to participate and for the challenging discussion. Another version of the paper was presented at the UCLA law school workshop series in March 2014. I am grateful to Kathy Stone for inviting me, and to the participants for excellent comments. I also wish to thank Leora Bilsky, Zvi Triger, and Simon Rabinovitch for reading a previous draft and making very valuable suggestions, and IRAC's legal counsel Ms. Orly Erez Likhovsky for helpful discussions. Andrew Smith, Caleb French, and particularly Elizabeth Nagle deserve special thanks for fine editorial work.

PNINA LAHAV is a Professor of Law at Boston University, and a graduate of the law school at the Hebrew University of Jerusalem and Yale Law School. She teaches constitutional law, first amendment law, and matters of foreign affairs. At present she is writing a biography of Golda Meir through the lens of gender.

\section{NOTES}

1. Both principles appear explicitly in Israel's Declaration of Independence and have been consistently honored by the courts.

2. For a general review of the Court's contribution to political and civil liberties and of the backlash that followed, see Lahav (2009: 135).

3. Shakdiel v. Minister of Religions, HC 153/87 42(2) PD (22) 1309.

4. Poraz v. Shlomo Lahat, Mayor of Tel Aviv, HC 953/87, 42 (2) PD.

5. See Sered (1997) comparing these two cases to the case of WoW and concluding that WoW was qualitatively different and therefore unlikely to win.

6. Indeed, the leaders of ICWoW dedicated their book on the subject "to the State of Israel" (Chesler and Haut 2003).

7. "We were tying one hand behind our back by shunning the general media and negative publicity for Israel, but concern about damaging Israel took precedence at that time" (Aronoff 2003: 187).

8. There is one bright line that the US Jewish community will not let the Israeli rabbinate cross, the issue of conversion, also known as 'Who is a Jew'. Repeated efforts by the Israeli Orthodox establishment to change the law of 
return to recognize only Orthodox conversions have consistently met with firm opposition by the American Jewish leadership. See, e.g., Bronner (2010).

9. Note that American Jewish politics remain relevant, as much of the emotional and financial support for the cause has depended on US good will.

10. Israeli Orthodox women, however, are discouraged from attempting to introduce gender equality into the synagogue ritual (Hartman 2007).

11. In 1989, the regulations were amended to prohibit religious rituals not held in accordance with the 'custom of the space' (minhag hamakom) and which offend the feelings of the worshippers toward the space (Kovetz Takanot 5237: 190, 12.31.1989; Rubinstein and Medina 2005: 378). Note that the term "space" was cleverly chosen. The Hebrew word for space is makom, which can also be used as a synonym for God. This can therefore imply that the banning of women from communal prayer is the will of God. Similarly, the offense to the feelings of the worshippers is 'toward the makom,' i.e., towards God.

12. Daniel Sperber is an eminent rabbi as well as Professor of Jewish Law at Bar Ilan University.

13. The Rabbi of the Wall was quoted as saying that "a woman carrying the Torah is like a pig at the Wailing Wall" (Sered 1997: 139).

14. Evidently at the beginning, the ICWoW was not sufficiently attuned to the feminist aspect of the controversy and more focused on the religion/state aspects of it. Raday represented WoW throughout the litigation before the Supreme Court and has written extensively on the subject.

15. See R. Hirschl's theory that WoW's marginality led to their defeat in the Court (2004).

16. Hoffman v. Western Wall Commissioner (the Rabbi of the Wall), 48(2) PD 265 (1994).

17. Hoffman v. Prime Minister Office, Tak-Al 2000(2) 846. Quite naively and shortsightedly, I celebrated the opinion as a happy ending to the saga (Lahav 2000: 19).

18. Further hearing of 4128/00, Director of Prime Minister's Office v. Hoffman, 47(3) PD 289.

19. See also http:/ / womenforthewall.org/.

20. The first woman to be arrested was Nofrat Frenkel. The deterrent effect of such an arrest is significant. Frenkel was a medical student, and a conviction could jeopardize her eligibility to get a license to practice medicine. For Ms. Frenkel's description of the event see http:/ /judaism.about.com/b/2009/11/24/ in-her-own-words-nofrat-frenkel.htm (last visited 29 July 2011). http:// www.huffingtonpost.com/anat-hoffman/arrested-for-praying-at-westernwall_b_1987099.html.

21. For a particularly insightful discussion of WoW from a secular Israeli perspective, see Dekel (2013).

22. "Number of Days" appeal no. 23834-04. Unpublished; author's archives.

23. See also Nehushtan (2013), criticizing the methodology of Sobel's opinion as too formalistic (while agreeing with the result).

24. http://index.justice.gov.il/Pubilcations/Articles/Pages/HadaratNasim. aspx (in Hebrew). 
25. See Jobani and Perez (2014) for analysis of this plan and a normative solution suggested by the authors. For a summary of the plan see Sattath (2013).

26. WoW founders Rivka Haut and Phyllis Chesler were among the signatories of the statement denouncing the plan. Most signatories gave a US address and were presumably from the Diaspora.

\section{REFERENCES}

Aronoff, Susan. 2003. “The Politics of the Women of the Wall." Pp. 180-204 in Chesler and Haut, 2003.

Aharoni, Leah. 2013. "Women of the Wall: An Agent of Contention." Sh'ma Journal, October, 5.

Barzilai, Gad. 2003. Communities and Law: Politics and Cultures of Legal Identities. Ann Arbor: University of Michigan Press.

Benson, Miriam. 2003. "The Lawsuit: 1989-Present." Pp. 136-158 in Chesler and Haut, 2003.

Berman, Daphna. 2013. "Anat Hoffman Dares to Take on Israel's Orthodox Establishment. Can She Win?" Moment, March-April. http:/ / www.momentmag. com/anat-hoffman-dares-to-take-on-israels-Orthodox-establishment-can-shewin $/ 3 /$.

Bronner, Ethan. 2010. "Israel Puts Off Crisis Over Conversion Law." New York Times, 23 July. http:/ / www.nytimes.com/2010/07/24/world/middleeast/ 24israel.html (accessed 29 August 2014).

Chesler, Phyllis, and Rivka Haut, eds. 2003. Women of the Wall: Claiming Sacred Ground at Judaism's Holy Site. Woodstock, VT: Jewish Lights Publishing.

Chesler, Phyllis. 2013. "Sh'ma Yisrael: Our Inalienable Rights as Jews and as Women." The Times of Israel Blog, 7 November. http:/ / blogs.timesofisrael. com/shma-yisrael-our-inalienable-rights-as-jews-and-as-women/ (accessed 29 August 2014).

Dekel, Daniela. 2013. "London Speaking to the Wall." [In Hebrew.] Yediot Acharonot (Shiva Yamim), 14 June: 32.

Grossman, Susan. 2014. "Rivka Haut, Quiet Warrior Who Battled For Orthodox Women, Dies." Forward, 2 April. http:/ / forward.com/articles/195683/rivkahaut-quiet-warrior-who-battled-for-Orthodox/ (accessed 11 September 2014).

Haberman, Bonna. 2003. "Drama in Jerusalem." Pp. 3-41 in Chesler and Haut, 2003.

Halperin-Kaddari, Ruth. 2004. Women in Israel: A State of Their Own. Philadelphia: University of Pennsylvania Press.

Hartman, Tova. 2007. Feminism Encounters Traditional Judaism. Lebanon, NH: Brandeis University Press.

Hirschl, Ran. 2004. Towards Juristocracy: The Origins and the Consequences of the New Constitutionalism. Cambridge, MA: Harvard University Press.

Jobani, Yoval, and Nachshon Perez. 2014. "Women of the Wall: A Normative Analysis of the Place of Religion in the Public Sphere." 3 Oxford Journal of Law and Religion, 484.

Katzir, Yael. 2009. Praying in Her Own Voice. Film, Israel. 
Lahav, Pnina. 2000. “Up Against the Wall." Israel Studies Bulletin 16: 19-22.

Lahav, Pnina. 2009. "Israel's Supreme Court." Pp. 135-158 in Contemporary Israel, ed. R. O. Freedman. Boulder, CO: Westview Press.

Lahav, Pnina. 2013a. "Women of the Wall: A Temporary but Meaningful Milestone." 9 HaMishpat Online: Human Rights - Insight into Recent Judgments 4.

Lahav, Pnina. 2013b. "The Women of the Wall: American Jewish and Israeli Feminism." Sh'ma Journal, October, 5.

Lederman, Faye. 2000. Women of the Wall. Film, USA. http:/ / www.newday.com/ films/WomenoftheWall.html.

Mautner, Menachem. 2010. Law and the Culture of Israel. Oxford: Oxford University Press.

Nehushtan, Yossi. 2013. "The Matter of the Women of the Wall: The Need for a Normative-Liberal Decision." [In Hebrew.] 9 HaMishpat Online: Human Rights - Insight into Recent Judgments 4.

Raday, Frances. 2003. "The Fight against Being Silenced." Pp. 115-133 in Chesler and Haut 2003.

Rubinstein, Amnon, and Barak Medina. 2005. The Constitutional Law of the State of Israel, vol. 1. [In Hebrew.] Tel Aviv: Shocken Press.

Sattath, Noa. 2013. "Struggling for Jewish Pluralism in Israel." Fathom 4: 69.

Sered, Susan. 1997. "Women and Religious Change in Israel: Rebellion or Revolution." Sociology of Religion 58, no. 1: 1-2.

Shakdiel, Leah. 2002. "Women of the Wall: Radical Feminism as an Opportunity for a New Discourse in Israel." Journal of Israeli History 21, no. 1: 126-163.

Shochetman, Eliav. 2010. "Aliyyot for Women." Pp. 291 in Women and Men in Communal Prayer, eds. Daniel Sperber, Mendel Shapiro, Eliav Shochetman, and Shlomo Riskin. Jersey City: Ktav/JOFA.

Sperber, Daniel, et al. 2010. Women and Men in Communal Prayer. Jersey City: Ktav/JOFA.

Triger, Z. 2013. "Gender-Based Segregation as Sexual Harassment." [In Hebrew.] Iyuney Mishpat 35: 703.

Woods, Patricia. 2008. Judicial Power and National Politics. New York: State University of New York Press. 